Fecha de recepción: junio 2020 Fecha de aceptación: julio 2020 Versión final: septiembre 2020

\section{El tiempo fantástico en la literatura latinoamericana del siglo XX y su transmutación al soporte gráfico del cómic}

Esmeralda Ríos ${ }^{(1)}$

Resumen: El presente artículo propone al soporte físico como estructura narrativa partiendo del concepto de cronotopo literario -relación espacio-tiempo con intención estética en la literatura- de Mijaíl Bajtín y el contraste con la literatura latinoamericana del siglo XX. Si bien el tiempo en la narrativa gráfica se encuentra en la representación visual del espacio, analizado por Linden, Barbieri, McCloud, entre otros, mi premisa es que el tiempo en dicha narrativa realmente habita en los espacios en blanco entre viñetas y plantea el análisis del soporte en el cómic y la posibilidad de experimentar con él para profundizar en el discurso narrativo -a la vez que sugiere un clasificado con base en su alteración-. La propuesta es la transmutación de dichos espacios blancos en suajes, fuelles, desplegables y otros recursos que devengan en un formato/soporte alternativo para lograr una percepción temporal distinta en el lector, y así mismo, darle la sensación de ser co-creador del relato; a su vez, dicha alteración del soporte narrativo convencional se traducirá en tiempo fantástico. Esta concepción de los soportes gráficos puede incidir también en nuevos esquemas editoriales y en un tipo de lector distinto.

Palabras clave: Narrativa gráfica - Cómic - Soporte físico - Literatura latinoamericana Tiempo.

[Resúmenes en inglés y portugués en las páginas 139-140]

(1) Licenciada en Diseño y Comunicación Visual por la ENAP, UNAM, México. Diplomada en Creación Literaria por la SOGEM, cuenta con estudios de ilustración, historieta, cine, animación y literatura en México, España e Italia. Autora de los libros ilustrados: El gato que come estrellas (Chilpayates, 2012) y Un huipil para la Muerte (Artes de México, 2015), así como de la novela Réquiem para un pez escarlata (UNAM, 2019). Seleccionada como ilustradora en la Biennial of Illustrations Bratislava, el BookILFest (Serbia), y el Catálogo de Ilustradores CONACULTA. Su investigación fue seleccionada para el Congreso Internacional "Comics in Dialogue", de la Universidad Complutense de Madrid, 2020. Actualmente es profesora en la Facultad de Artes y Diseño, cursa la maestría en la UNAM, y trabaja en sus propios proyectos gráficos/literarios. 
La presente comunicación forma parte de una investigación más amplia acerca de las posibilidades narrativas dentro de la Narrativa gráfica en general al hacer uso de herramientas similares a las utilizadas en la literatura, en concreto, la llamada Literatura fantástica latinoamericana que abarca la segunda mitad del siglo XX, caracterizada por su basta experimentación con el lenguaje, la estructura y el contenido, además de encontrar en sus raíces la nueva concepción del universo producto de los descubrimientos de la Física cuántica y la enunciación de la Teoría de la Relatividad.

El tema propuesto es la exploración del tiempo a través de la alteración del espacio (soporte/formato) dentro del cómic y su relación con la percepción temporal para generar un efecto fantástico o de realidad alterada en el lector, partiendo de los recursos narratológicos de los que se valieron algunos de los autores más representativos del periodo referido. De ahí que utilice el término "transmutación" para referirme a la interpretación gráfica de dichos mecanismos. Este concepto -también conocido como "traducción intersemiótica" - fue introducido por Roman Jakobson, para referirse a "la interpretación de los signos lingüísticos mediante sistemas de signos no lingüísticos" (Jakobson, p. 119, citado por Cid 2006).

Lo que me propongo transmutar es el tiempo a soporte estructural para generar una sensación de espacio-tiempo fantástico en el lector. Es en este punto donde entra en juego la concepción de soporte como elemento no lingüístico y como representación del espaciotiempo narrativo.

Comenzaré por establecer referencias teóricas para el análisis del tiempo narrativo en la literatura Latinoamericana del siglo XX; posteriormente, haré un repaso por el soporte gráfico-estructural y los espacios vacíos de la narrativa gráfica para aterrizar en la premisa aquí planteada.

\section{El tiempo fantástico en la literatura latinoamericana del siglo $\mathrm{xx}$}

Lanzarnos a una definición del tiempo $o^{1}$, resultaría, no sólo arriesgado sino fútil; son muchos los filósofos, científicos, teólogos, entre otros, que han dedicado sus horas a tan complicada tarea, y cada una de estas visiones presenta la posibilidad de exquisitos juegos narrativos. En la variedad de posturas acerca del tiempo es que podemos encontrar lo maravilloso. Es un hecho que en el periodo en que los escritores aquí analizados realizaron su producción literaria, el mundo, sus representaciones y definiciones se encontraban en plena evolución gracias, y a principios del Siglo XX, la Teoría de la Relatividad General, que puso en la mesa la concepción de tiempo individual y subjetivo, es decir, que el tiempo depende del punto espacial en el que se encuentre su observante. El aporte más radical de dicha teoría es el pasar de tiempo a espacio-tiempo.

Tantos espacios-tiempos como observantes en esta Tierra... Infinitas posibilidades y universos, la segunda gran revolución que trajo la relatividad: La mecánica cuántica de Moravek y sus múltiples universos.

La teoría narrativa no escapó a esta transformación científica y de pensamiento, encontrando voz en críticos literarios como Mijaíl Bajtín, quien a partir del cronotopo propuesto 
por las matemáticas relativistas de la época, desarrolla el concepto de cronotopo literario para explicar la relación espacio-tiempo en la literatura, los cuales son inseparables: "Vamos a llamar cronotopo (lo que en traducción literal significa "tiempo-espacio") a la conexión esencial de relaciones temporales y espaciales asimiladas artísticamente en la literatura" (Bajtín, 1989, p. 237).

En narratología bajtiniana los cronotopos surgen del conjunto de características de una determinada literatura, ya sea por época, temática o autor, es decir, que pueden existir inclusive cronotopos dentro de otros cronotopos. Expresiones temporales, descripciones espaciales, enlaces, transiciones, estructura, entre otros, la forma y el contenido están dados por estos elementos. El espacio construye al tiempo mas el tiempo transforma al espacio. Simbiosis indisoluble.

En el cronotopo fantástico del siglo XX los espacios son cotidianos, entornos cercanos al lector, y por tanto, el tiempo que le toma recorrerlos es tan variable como su propia experiencia en ellos; la temporalidad es subjetiva y propia de sus personajes, más el efecto de extrañamiento ocurre al confrontarla con la del narrador y del propio lector. No todo lo fantástico está dado por la alteración del tiempo, pero toda alteración del tiempo cronológico resulta fantástica. Entiéndase por este último el tiempo diegético, así denominado por Genette y recogido de Luz Aurora Pimentel (2017). Es decir, dentro de la narrativa encontramos, cuando menos ${ }^{2}$, seis tiempos:

El del autor -el tiempo que tarda en ejecutar la obra-, el diegético -la duración de los hechos reales ocurridos en la historia-, el tiempo gramatical -determinados por la conjugación de los verbos según la persona gramatical elegida de acuerdo con el espacio temporal de enunciación del narrador-, el del discurso -el espacio y la sucesión textuales que dichos acontecimientos ocupan en la narración-, el derivado de la estructura cronológica, también conocido como anacronías - selección de las elipsis temporales y su ordenamiento dentro del relato, de cuya relación depende el tempo narrativo-; y el tiempo del lector-el que tarda en leer la obra-, y es en estos últimos que grandes autores han encontrado la materia prima para crear lo fantástico: Borges, Garro, Bioy Casares, Cortázar, Fuentes, Dávila, García Márquez.

Si en Rayuela Cortázar altera solo el orden de lectura a partir del tránsito del lector por el libro, derivando en una alteración temporal de carácter extradiegético -en otras palabras, fuera de la narración-, en otros textos del mismo autor y de los escritores mencionados, dicha alteración ocurre a nivel metadiegético -es decir, dentro del relato- y sin modificar el tránsito del lector.

En las anacronías de orden "normal" los eventos son presentados al lector textualmente de manera secuencial. Es decir, sin importar la elección del autor de comenzar a narrar la historia in extrema res, por ejemplo, o de manera cronológica, el recorrido del lector por el libro es intrínsecamente lineal de la primera a la última página.

En la estructura, llamémosle, de orden "transitable", la narración mantendrá un orden lineal, pero es su tránsito el que se verá alterado, provocando al lector a desplazarse por el objeto-libro en un orden discontinuo.

De acuerdo con el mismo Cortázar en sus Clases de Literatura: Berkeley, 1980, “....el tiempo es un elemento poroso, elástico, que se presta admirablemente para cierto tipo de manifestaciones..." (Cortázar, 2016, p. 51), enumera una serie de tiempos fantásticos ${ }^{3}$ : el 
mental, el interno, el que se estira, el que se desdobla, el paralelo, el simultáneo, y un sinfín que el creador puede concebir. Cada uno de ellos es un cronotopo en sí mismo.

Para poner un ejemplo del literato del que podríamos llamar el cronotopo expandido, retomaremos "El perseguidor", cuento realista en el que sin embargo, hay un momento metadiegético en que uno de los personajes, Johnny Carter, relata al narrador una extraña experiencia temporal, calificable como fantástica, experimentada durante un recorrido en el metro -entorno cotidiano al lector-. El personaje Carter recuerda eventos de su pasado con todo detalle, se podría decir que los está viviendo, así, en presente. Cito:

-.... Entonces me vas a decir cómo puede ser que de repente siento que el metro se para .... y veo que estamos en Saint Germain-des-Prés, que queda justo a un minuto y medio de Odeón .... ¿Cómo se puede pensar un cuarto de hora en un minuto y medio? ... Las estaciones son los minutos, comprendes, es ese tiempo de ustedes, de ahora; pero yo sé que hay otro..." (Cortázar, 2014 a, p. 310).

En este fragmento se muestra como el tiempo real, compartido por todos, se alarga de manera imposible, de un minuto y medio a por lo menos quince minutos del tiempo interno de Carter; cosa que puede interpretarse a la inversa, es decir, que el tiempo interno se comprime dentro del tiempo compartido.

Dicho efecto de estiramiento del tiempo lo encontramos también con una variante en otro cuento del mismo Cortázar, La autopista del Sur: Aquí el tiempo tiene una duración "normal", son los hechos los que se extienden por él, alargando un embotellamiento de horas a meses. "Cualquiera podía mirar su reloj pero era como si ese tiempo atado a la muñeca derecha o el bip bip de la radio midieran otra cosa..." (Cortázar, 2014 b, p. 179). Una constante del cronotopo fantástico del siglo XX es la advertencia, por parte del narrador, de que se está ingresando en un tiempo distinto, con lo que elimina la posibilidad de vacilación: el hecho fantástico es.

Otro ejemplo de cronotopo podría ser el circular, para lo que nos sirve La invención de Morel, de Adolfo Bioy Casares: la historia de un prófugo resguardado en una isla habitada sólo por un puñado de turistas y el mismo reo; este se enamora de un solitaria mujer, más descubre que ella es solo una proyección eterna. Este perpetuum mobile resulta un bucle temporal autoinducido como mecanismo mnemónico y con posibilidad de "devenir" en los deseos del protagonista, quien piensa, es posible superponer su propia proyección temporalidad- a la de ella.

La clave de este cronotopo es la repetición de los hechos tal cual se han presentado. Su base, la teoría del Eterno Retorno de Nietzche. "Creí haber hecho este descubrimiento: en nuestras actitudes ha de haber inesperadas, constantes repeticiones... Como en el teatro, las escenas se repiten" (Bioy, 2014, pp. 46-47). Derrida nos habla de una fantontología que "caracteriza, tanto al hombre muerto que regresa, como al fantasma cuyo esperado retorno se repite una y otra vez" (Derrida, pp. 31-50 citado por Fóster 2001). En ambos casos, la clave es la búsqueda de la inmortalidad o de un tiempo infinito.

En Aura (2012) de Carlos Fuentes se cumple esta teoría a la perfección: Felipe Montero acude a una casa de la Ciudad de México debido a una solicitud de empleo. En ese lugar 
viven dos mujeres, Consuelo, una anciana viuda y su joven sobrina, Aura. La condición es que el profesor no puede salir de la casa hasta ordenar las memorias del general, esposo de Consuelo. Felipe descubre que Aura no es otra que Consuelo y que él mismo es la reencarnación del general. En este ejemplo, el tiempo circular existe únicamente dentro de la casa, solo para los personajes existe un perpétuom mobile; como lectores, podemos inferir que al exterior el tiempo continúa su curso, por ello Montero es capaz de regresar allí. La casona es una isla, semejante a la de Morel. Pareciera aquí haber otra condición del cronotopo circular: la célula o aislamiento, como si el Eterno retorno pudiese obrarse sólo en espacios reducidos, pues su reiteración depende de la voluntad de los hombres, mas el poder de estos es limitado.

Un último ejemplo de alteración temporal aquí abordada, es el cronotopo bifurcado, probable precursor de la teoría cuántica de los mundos paralelos. En "El jardín de senderos que se bifurcan", Borges ensaya con este tiempo. Aunque el cuento tiene una estructura lineal sin anacronías, lo que el literato plantea es la existencia de líneas paralelas. El protagonista descubre el libro en apariencia sin sentido de T'sui Pên -el héroe del mismo aparece vivo y muerto en distintos momentos de la historia-, de esta forma descubre que El jardín de senderos que se bifurcan se refiere a las múltiples posibilidades de líneas temporales contenidas en ese libro: “...la frase varios porvenires (no a todos) me sugirió la imagen de la bifurcación en el tiempo, no en el espacio” (Borges, 2000, p. 112).

Si bien Borges sólo ensaya en su relato sobre el tiempo bifurcado, Bioy Casares sí hace uso de él en "La trama celeste" (2015), que trata la historia del capitán Irineo Morris, quien tiene como misión probar un avión para el ejército y como consecuencia viaja sin saberlo a "distintos" Buenos Aires, líneas temporales que difieren de la del personaje. A este cronotopo lo caracteriza el uso de los mismos espacios pero con pequeñas variantes.

La apuesta es que, gráfica y materialmente, cada uno de estos universos planteados, poseedores de su propio espacio-tiempo, podría tener una representación y una estructura propias. Mi interés en la presente ponencia es ceñirme al soporte físico como estructura narrativa.

\section{El soporte gráfico y sus stadiums}

Hasta este momento, el soporte es, por lo general, visto como un mero contenedor de signos lingüísticos y gráficos, que si bien es necesario para transmitir el mensaje, generalmente puede ser sustituido sin restar o sumar consistencia al enunciado, por ejemplo, al pasar una obra literaria o novela gráfica del papel a formatos digitales; si bien el e-book presenta ciertas ventajas -como la manipulación del puntaje tipográfico por parte del lector para su mayor comodidad-, este hecho no altera el discurso presentado. La riqueza consiste en utilizar dicho soporte como engranaje crucial o aun generador de contenidos. Distinto al e-book es el caso del web cómic, que al aprovechar sus cualidades virtuales, presenta mayor juego con los espacios entre viñetas para generar suspense y tensión narrativa a partir de la variabilidad del tempo narrativo. Empero, el pretender por ello llevar el cómic a una plataforma digital en busca de una (aparente) infinitud-como propone el 
Infinite canvas (2009) ${ }^{4}$ de McCloud- sólo reforzaría su intangibilidad: la apuesta es asir el tiempo, al menos dar la ilusión de que es posible, por momentos, manipularlo.

Quizá en esto el soporte del cómic concebido para medios impresos poco se ha apartado de la idea de la página como unidad de secuencia narrativa básica -si se parte de la propuesta de Will Eisner (1994) de la viñeta como unidad mínima espacio-temporal dentro de la historieta-, si bien, como señala Manuel Barrero (2012), el hablar de una "página de historieta" en el esquema tradicional corresponde a una distribución de los elementos narrativos del cómic en el anverso y revés de las hojas del papel, pero sin aludir a la superficie de su publicación, la cual puede ser variable. Para el investigador, un mejor término que "página" es el de plana, que permite la flexibilidad de formato y del espacio destinado para su publicación según el medio. Sin embargo, aunque el mismo Barrero prevé la importancia de explorar las cualidades del soporte, no sugiere en concreto cómo podría darse una ruptura, además, piensa el soporte casi como un sinónimo de formato, siendo que este se refiere a las dimensiones del papel -en cuanto a las publicaciones impresas, las que aquí nos ocupan-, no tanto a la forma de encuadernación alternativa derivada de la modificación del libro códex como tal, ni de su relación directa de este con la narración. Para fines de claridad, me detendré en el soporte físico, el contenedor por excelencia de las obras literarias y gráfico-narrativas, al menos hasta finales de la década de los ochenta del siglo XX: El libro material, construido principalmente de papel y cartón, bajo su forma más convencional, el libro códex, entendido este como compuesto por cuadernillos de folios plegados, cosidos y encuadernados - de manera rústica o tapa dura-, que devienen, casi siempre, en una lectura lineal; linealidad que remite a un tiempo cronológico -aunque no es condición ser así-. Lo que es un hecho, es que transitamos ${ }^{5}$ una obra, ya sea literaria o gráfica, pasando sus páginas, una detrás de otra, de manera consecutiva y de principio a fin, ya sea de izquierda a derecha al modo occidental, o de derecha a izquierda al estilo oriental -es en este nivel, al que llamaré primer stadium para fines de clasificación, que se sitúa la gran mayoría de los cómics y los textos literarios-. (Ver Cuadro 1)

En este primer stadium encontramos propuestas de innegable experimentación narrativa y cronotópica. Tal es el caso de Here (2014), de Richard McGuire, novela gráfica en la que el protagonista es un encuadre en el espacio, y a través de sus páginas y del constante juego de incrustación -según nomenclatura de Iván Pintor-, es decir, viñetas a doble página, en este caso rebasadas, en las que continuamente se insertan viñetas de variadas dimensiones, sin aparente reticulación definida, al estilo de ventanas que muestran el mismo espacio en otro punto cronológico. Si bien, debido a su carácter contemplativo, se presta al capricho estético del lector de abrir el libro en cualquier página y saltar de una a otra sin orden, se asume, por ciertas viñetas clave presentadas en los puntos correspondientes al inicio, desarrollo y desenlace de la narración, que hay una intensión de lectura lineal (Ver Figura 1). En algunos casos, el orden convencional de lectura se ve alterado al proponer al lector ir y volver, saltear páginas cual si acechara las pistas de un misterio, presentándosele varias opciones lo que lo hace "interactivo": leer de manera consecutiva o seguir una indicación en zigzag en la que, si bien, el lector no cuenta con un abanico de posibilidades infinita, lo saca de su pasividad y del "andar rutinario" al que está acostumbrado al momento de leer. 


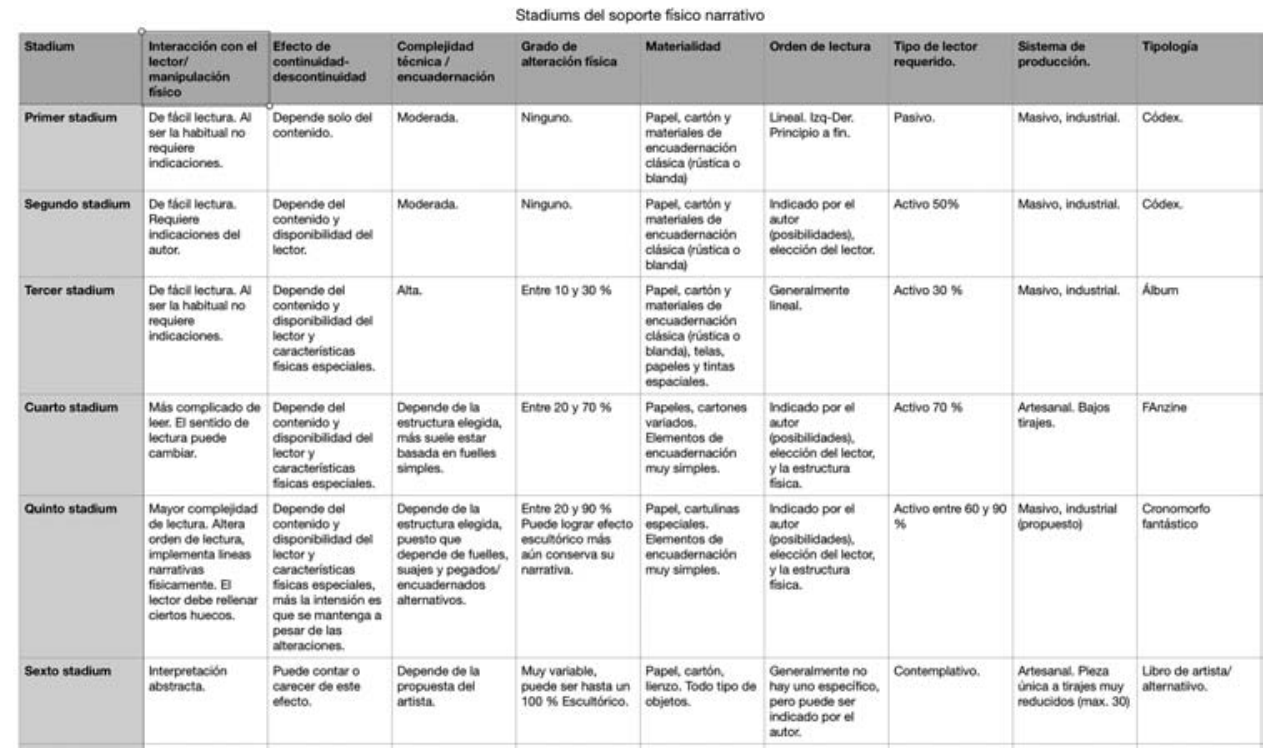

Cuadro 1. Clasificación que propongo para definir distintos grados de alteración del soporte físico (objeto-libro).

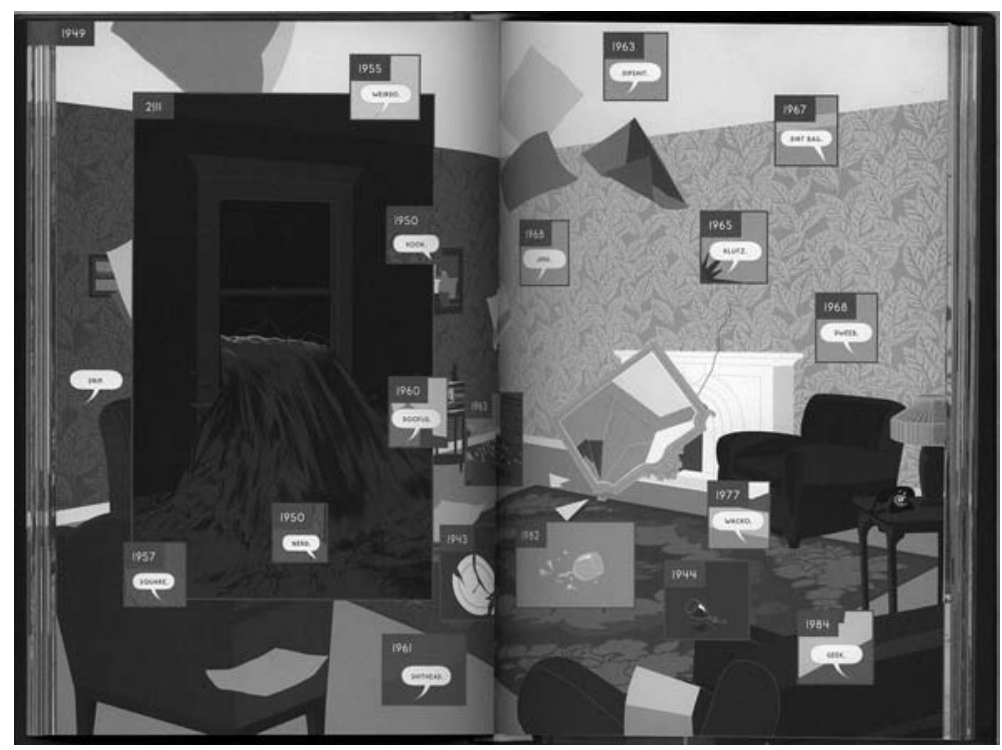

Figura 1. Richard Maguire, Here (2014). 
Tal es el caso de la novela Rayuela de Julio Cortázar. Lo que resulta fantástico de Rayuela en sí, no es lo que ocurre en la trama sino la manera en que esta es contada. No existe interferencia en la cronología de los hechos, sino en la forma de percibirlos por el lector, aportando información adicional que en ocasiones da pistas y en otras verosimilitud y contexto a la trama de Oliveira. El literato apunta en el prólogo: "A su manera este libro es muchos libros, pero sobre todo es dos libros. El lector queda invitado a elegir una de las dos posibilidades siguientes" (Cortázar, 2019, p. 3), el que Cortázar destaque la expresión “a elegir", implica la ruptura de la literatura clásica, aquella en la que el lector era un mero espectador de los eventos relatados y marca la pauta de lo que será el lector-coautor.

Rayuela, considero, también abre la posibilidad a las múltiples lecturas y por ende, a los múltiples universos dentro de una misma apuesta. El lector debe modificar su tránsito unidireccional por el objeto-libro para descubrirlos, y con él, abandonar las certezas. Mas este es apenas un segundo stadium de las posibilidades del libro-objeto, ya que su estructura física aún mantiene las características y la apariencia del tipo códex.

A este stadium pertenece, por ejemplo, la novela gráfica de Jason Shiga, Meanwhile. Al igual que Cortázar en Rayuela, Shiga coloca al inicio una "advertencia" seguida de las instrucciones de lectura de la novela: "STOP! This is not an ordinary cómic!" (Shiga, 2010, p. 3), las páginas poseen una pestaña a manera de agenda que representan "tubos" que conectan unos paneles con otros, así el lector puede elegir entre una combinación muy amplia de posibilidades para seguir la trama que, a su vez, se torna en muchas historias (Ver Figura 2).

Sophie Van der Linden describe al álbum como "un soporte sobre el que se inscriben las imágenes y el texto, caracterizado por la interacción entre texto e imagen” (Linden, 2015, p. 16). La clave está en el se inscriben, los elementos que conforman a este tipo de narrativa son vaciados sobre un soporte, un espacio físico. Según Linden, las dimensiones y materialidad del álbum son de gran relevancia en el motivo narrado, ya que aportan una "dimensión significativa, incluso pueden llegar a adquirir un rol narrativo" (Linden, 2015, p. 10), por ello, no es extraño el empleo de materiales poco convencionales: barnices, troqueles, papeles de texturas o acabados especiales, telas, entre otros, además de formatos dispares entre álbumes. En este caso, texto, imagen, formato y soporte se conjugan todos para dar una intención narrativa. Esto es lo que considero un tercer stadium del objeto-libro. Los álbumes narrativos de la escritora e ilustradora checa Květa Pacovská constituyen un testimonio fiel de las posibilidades del objeto-libro (Ver Figura 3).

En ocasiones alejándose del códex, y opuestos a la "opulencia" del álbum, encontramos los fanzines ${ }^{6}$, que se componen de formatos más diversos y encuadernaciones sencillas -costura simple, anillado o engrapado- o nulas, que presentan dobleces particulares. En este clasificado el cuarto stadium, podemos encontrar una gamma de ejemplos entre el llamado cómic underground o también en el cómic independiente, debido a que sus características permiten un bajo costo de producción, mas presenta la desventaja de reproducirse en reducidos tirajes y contar con una distribución bastante limitada, de ahí que se mueva sólo entre su círculo cercano de lectores y en convenciones de cómic. Quizá, alguna excepción afortunada encuentre cabida en los puntos de venta de alguna librería local. Empero, no todo es desventaja en estos, pues ese mismo carácter que lo aleja de lo masivo le permite al cómicfanzine abordar temáticas y estilos normalmente censurados por el engranaje editorial. 


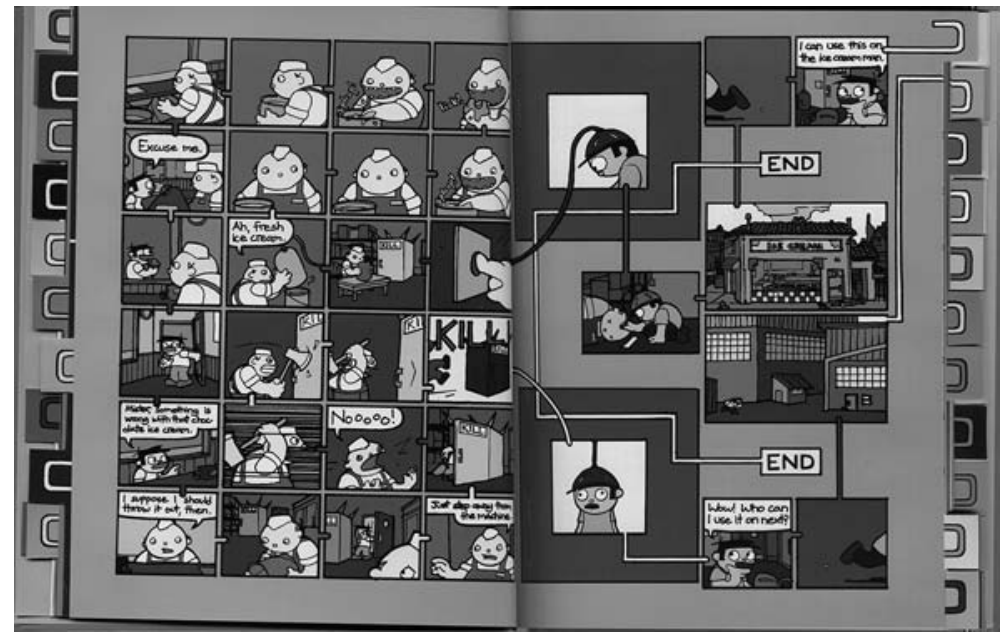

2

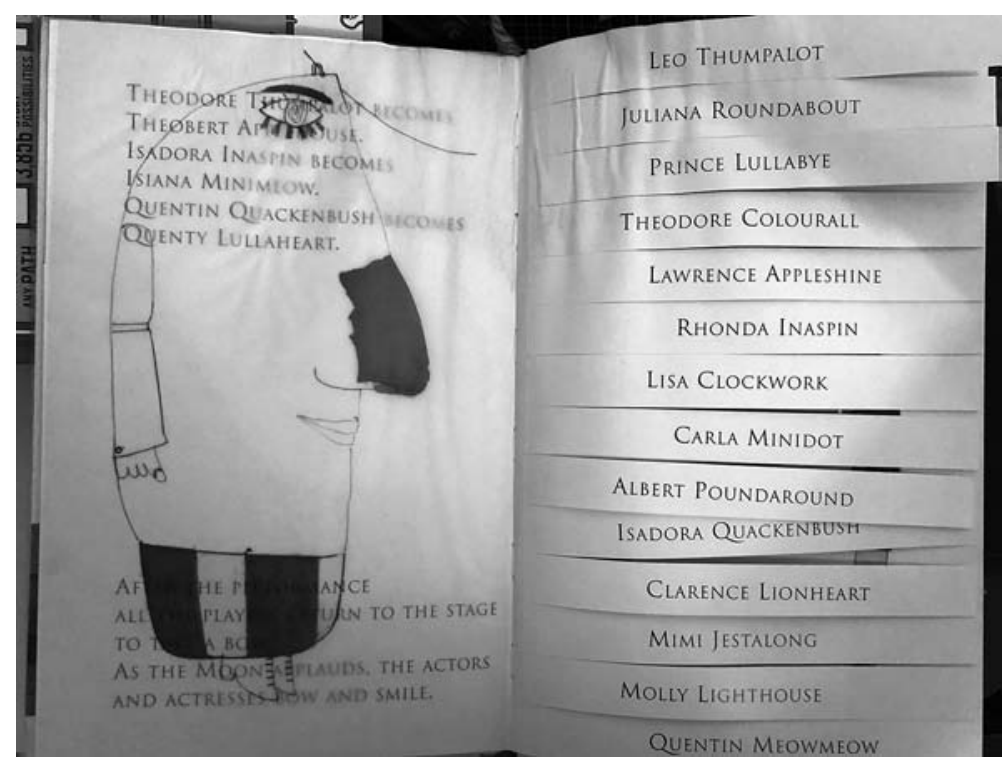

3

Figura 2. Jason Shiga, Meanwhile (2010). Figura 3. Květa Pacovská, MidNightPlay (1992). 
El quinto stadium estaría habitado por la propuesta de la presente investigación, a la que he denominado el cronomorfo fantástico, derivado del cronotopo literario, pero para mayor entendimiento es necesario explicar -por lo que volveremos al quinto stadium más adelante- lo que he clasificado como el sexto stadium: los libros alternativos y de artista7. Raúl Renán llama a estos "los otros libros", que son transformados en "caprichosas variantes de la escultura" (Renán, 2009, p. 10); se trata de aquellos en los que se busca la deconstrucción del libro, que en casos extremos, no conserva nada de sus cánones -es decir, elementos como las cubiertas, el lomo y los cantos, pierden sus contornos hasta desaparecer por completo-.

Para el artista y teórico Ulises Carrión el libro es "una secuencia espacio-temporal" (Carrión, 2012, p. 38), lo que implica que es narrativo por sí mismo; es muy importante desde su óptica el libro como ente autónomo, capaz de contener cualquier lenguaje escrito y otros sistemas de signos, de donde podemos intuir, el lenguaje gráfico del cómic. Esta evolución del libro, según Carrión, vino desde la poesía, donde los poetas exploran con los espacios en blanco, las palabras o frases interrumpidas para generar un ritmo, es decir, que los espacios vacíos ya no son solo los que enmarcan y definen cada signo tipográfico, sino que constituyen parte del mismo poema y como tal, influyen en la forma en que el lector percibe el discurso y, por supuesto, el tiempo. Carrión y sus contemporáneos van más allá en la exploración del soporte a través de los materiales a extremos en los que el lector, como señala Renán, puede toparse con una pieza de carácter escultórico más que narrativo. El verdadero reto que nos ocupa, es mantener coherencia en la relación relato-discurso cronotópico-ingeniería escultórica editorial.

\section{El habitante del espacio vacío}
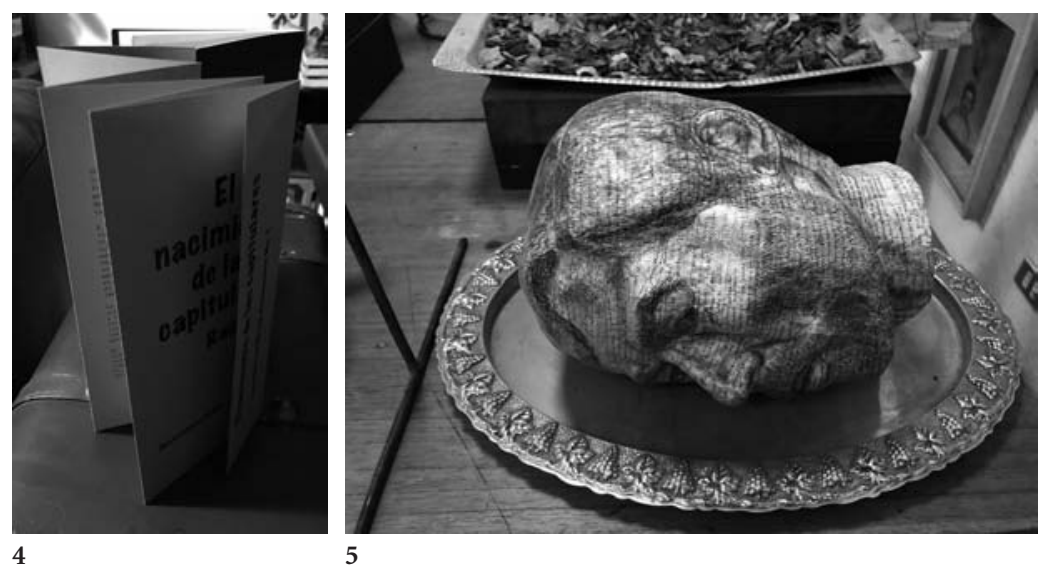

Figura 4. Raúl Renán

"El nacimiento de las capitulares”, (2010), fanzine. Figura 5. Libro de artista de Nahum Zenil. 
Estos espacios en blanco utilizados en la poesía, sin embargo, no resultan de novedad para la historieta, ya que son justo el recurso que le da un sentido espacio-temporal. Es decir, que algo que para el objeto-libro cobra importancia hasta los años setenta del siglo pasado, ha sido una característica inherente al cómic desde su origen.

Mucho se ha teorizado sobre el cómic en cuanto a la relación gráfico-textual y su, en apariencia, inalienable carácter secuencial. Eisner, McCloud, Barbieri, Peppino, Pintor, entre otros, han estudiado los elementos formales de la viñeta y sus posibilidades narrativas. $\mathrm{Si}$ bien algunos de ellos han hecho espacial énfasis en "la línea blanca que separa las diversas imágenes", como dice Barbieri (1993), es el lugar en el que aquí nos interesa profundizar. Para Eisner, los espacios están determinados por las dimensiones de la viñeta, y esta es la que establece el punto de visión del lector así como la duración de los hechos, mas el transcurrir del tiempo no lo expresa el contenido de la viñeta per sé, sino que actúa sólo como catalizador. En contraposición, para Barrero, "Las calles entre viñetas no son sino estructuras estandarizadas por la evolución del propio medio y nada aportan al relato salvo la indicación de que el lector debe hacer una pausa para reconstruir lo que las imágenes (de anteriores y posteriores viñetas) le sugieren" (Barrero, 2012, p. 38). Al mencionar "estandarizadas", el teórico pareciera aludir a la narrativa gráfica clásica, en la que la relación compositiva es hipotáctica ${ }^{8}$, es decir; que cada una de sus unidades narrativas de carácter gráfico guardan relación causal con la que le sigue, más en el presente estudio el interés se centra en el cómic moderno y el postmoderno, por lo que la afirmación de Barrero nos limita; si bien su argumento para refutar teorías como la de Eisner parece congruente - “a mayor espacio vacío entre viñetas, menor información iconográfica dispone el lector" (Barrero, 2012, p. 38)-, recarga todo el peso del discurso narrativo del cómic en la evidente relación imagen-texto, y olvida elementos fundamentales como el ritmo y la armonía -estudiados por Barbieri-, el pericampo -del que hablaremos más adelante-y el espacio físico o soporte, no en el que ocurre la narración, sino el que la contiene y crea a la vez.

El espacio en blanco es el vacío, pero, paradójicamente, sostengo, ese vacío está habitado por lo que hay en el relato de ausente. Se trata de un espacio simbólico en el que se construye la narración. Aún en el montaje en el que las imágenes parecieran tener un menor grado de secuencialidad, según McCloud, debiera haber "una especie de alquimia en funcionamiento en el espacio entre viñetas que puede ayudarnos a encontrar el significado o disonancia incluso en las combinaciones más discordantes" (McCloud, 2012 citado por Barrero, p. 38).

Siguiendo el mismo hilo de Barrero, formas diversas de generar el espacio-tiempo narrativo en el cómic pueden provenir del parahistorietema $a^{9}$ y aportar nuevas herramientas a los mecanismos narrativos gráficos. Del mismo enunciado de McCloud, la palabra discordante recuerda a Paul Ricouer cuando asegura que las discordancias temporales (2017) son las que crean los efectos narrativos más interesantes. Es aquí donde se construye lo fantástico. Para Barbieri, los espacios entre viñetas cumplen, en el sentido clásico más estricto, una función delimitadora del tiempo y del espacio que orienta la secuencialidad-: "generalmente lo que se sitúa a la derecha o debajo de una línea blanca es posterior a lo que sitúa a la izquierda o encima" (Barbieri, 1993, pp. 171-172), mas la historieta moderna tiende a eliminar el marco que delimita a la viñeta, con lo que el blanco del papel deja de ser exclusivamente divisorio para formar un tipo de ritmo distinto al generar una pausa o 
rallentando, lo que en teoría literaria se concibe como parte del tempo narrativo -del que Ricoeur y Pimentel hacen un desglose detallado-, por el contrario, comprimir dicho espacio aumenta la sensación de continuidad.

Según Barrero, la secuencialidad es un elemento inalienable del cómic en tanto que es condición de todo acto narrativo, empero, argumenta para hablar de la no condicionante de espacios divisorios entre viñetas, la existencia de aquellas en las que hay una secuencia pero que ocurre dentro de una única viñeta. Por ello, rechaza el modelo de "transiciones ${ }^{10}$ " de McCloud, mas no debemos ver ambas teorías como excluyentes, puesto que pueden cohabitar en una teoría más amplia y nunca definitiva. Esa viñeta única es excepción, y no regla. Podemos encontrar un ejemplo, en Seconds de Bryan Lee O`Malley (Lee, 2014, p. 23). El autor se vale de un solo espacio -delimitado por una viñeta única- en la que se comprime una secuencia temporal, entendida como tal mediante la composición de la viñeta-página que orienta la lectura, y de esta manera, el orden cronológico de las acciones, apoyándose del uso de los globos de diálogo y su contenido textual. Este recurso se combina con otros en puntos diversos de la novela como delimitación de viñetas, "cortes" arquitectónicos que permiten situar distintas acciones que ocurren a la vez en un mismo espacio dispuesto a doble página, entre otros que podríamos clasificar como transiciones aspecto a aspecto (Ver Figura 6).

Otro autor que hace uso poco convencional de las viñetas y la composición espacial de la página es Chris Ware, quien para lograr la narración de grandes espacios temporales o narraciones simultáneas, utiliza los espacios entre las viñetas para delimitar las acciones simultáneas dentro de la misma línea temporal -como en Rusty Brown (2019)- o juega con las composiciones infográficas -como en Jimmy Corrigan: The Smartest Kid on Earth (2000). El caso de Ware es particularmente interesante por su grado de experimentación con el formato; en su serie Building Stories (2014) presenta algunos códex de formato muy estrecho y alargado, plegables que recuerdan las hojas de un periódico, en lo que podría ser un acercamiento al fanzine -ya ubicado en el cuarto stadium del soporte-, pero de mayor producción. Las composiciones infográficas de Ware, así como los formatos por él elegidos, influyen en la percepción espacio-temporal y por ende, en el tiempo de lectura Pintor advierte (2017) que solo al lector pertenece la duración de la lectura de una viñeta-, el lector deberá decidir el orden de los libros facsímiles -que constituyen relatos cortos en sí mismos, a la vez que funcionan como capítulos-, por dónde comenzar a leer y construir historias, creando diversas combinaciones. El efecto de lectura es muy diverso en cada uno de los formatos, pues a mayores sean las dimensiones, no sólo equivale a más espacio diegético, si no que también resulta una experiencia más inmersiva, desde la manipulación del pliego hasta el recorrido visual (Ver Figuras 7, 8 y 9).

Se han abordado algunas posturas acerca del espacio entre viñetas, que divide, canaliza la acción, que crea un ritmo. Para esta investigadora, es un espacio vacío donde cabe el blanco de la página, el fondo cromático o la viñeta enmarcadora que algunos llaman continente; este vacío puede ser el espacio inhabitado, aquel que se representa por medio de cortes, dobleces, en resumen, por el confín de la página y el soporte. 


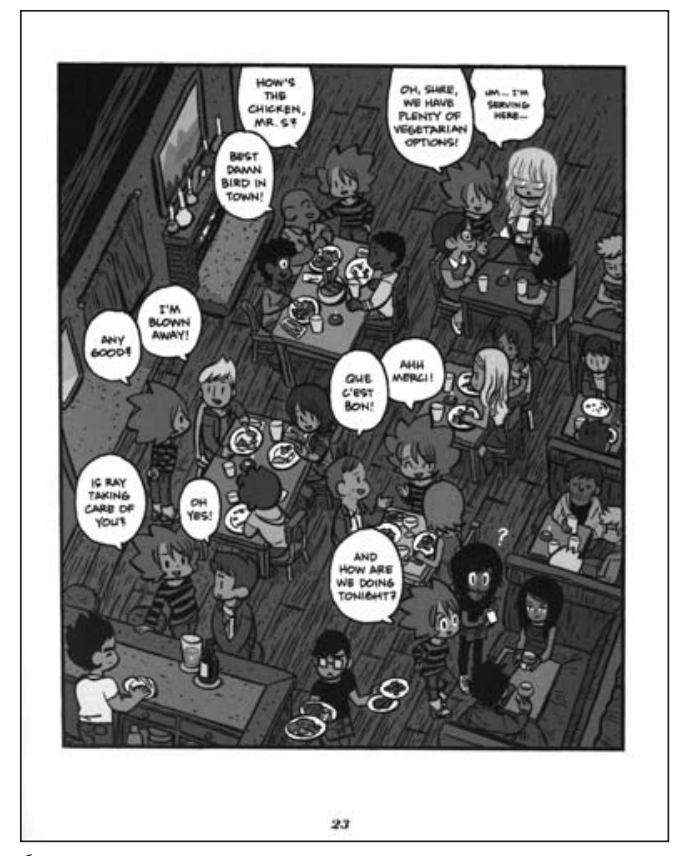

Figura 6. Bryan Lee

O'Malley, Seconds (2014).

Figuras 7, 8 y 9. Chris Ware,

distintos formatos para

Building Stories (2014).
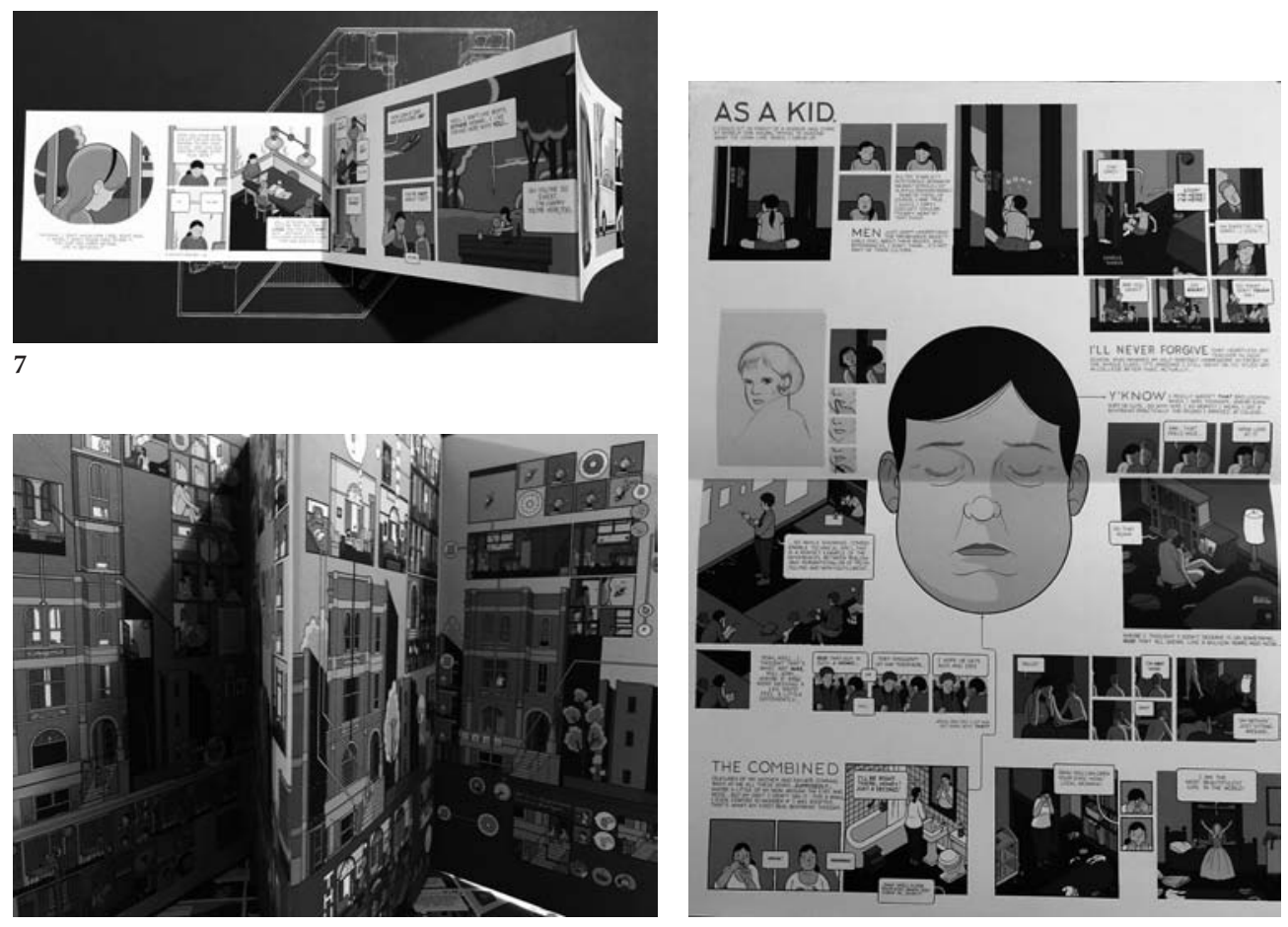

8 


\section{Un cronomorfo de lo fantástico}

Ya que hemos establecido algunas generalidades sobre el manejo del espacio-tiempo en la literatura latinoamericana del siglo XX y el uso de los espacios vacíos dentro de la historieta, es pertinente retomar a Bajtín para decir que el cronotopo gráfico se compone de dos dimensiones metadiegéticas: la iconográfica-la línea, el color o relleno, el texto o su ausencia, composición, profundidad, etc.- y la simbólica -significación del contenido-, y una extradiegética: los silencios o espacios vacíos entre el material icónico, dado que, si bien son asignados por el autor, su interpretación y carácter de secuencialidad le corresponden al receptor y su experiencia lectora; y es, posiblemente, esta dimensión la que confiere a la narrativa gráfica su tempo narrativo.

Así como en el cronotopo literario los espacios son descritos con mayor o menor detalle según se requiera variar el ritmo del relato y el tiempo está dado en el discurso por medio de las anacronías, en el cronotopo gráfico los espacios y elipsis están delimitados por el blanco que se erige entre un momento narrado y otro. La viñeta es un instante, pero solo la sucesión de instantes se convierten en tiempo, no en el tiempo que deviene de la duración -dada por la acción del instante-, sino en tiempo narrado.

Para Bajtín "[el] motivo cronoespacial del encuentro", que se refiere a las intersecciones o simultaneidades narrativas, "necesita de una extensión espacial abstracta" (Bajtín, 1989, p. 250). Bajo esta visión, es viable, aun menester, ir más allá del espacio en blanco -o blanco intericónico para Pintor- para sustituirlo por uno vacío, a su vez, traducido por fuelles, suajes, encuadernaciones alternativas que se alejen del formato códex, no como un capricho escultórico sino en aras de una narratología del tiempo. Esa "extensión abstracta" es posible encontrarla en la recuperación de los espacios vacíos que rodean cada una de las viñetas del cómic y su soporte, haciendo que este cobre otra dimensión. Ausencias que serán transmutadas en un formato distinto.

Como advierte Peeters, citado por Pintor (2017), existe un espacio abstracto, el pericampo, que es la percepción total de la página: lo que sabemos que está allí explícito alrededor de la viñeta que observamos -el resto de las viñetas-, y lo implícito -la narración que se construye de la suma de estas-. Lo que se ve y no se ve. Esta propuesta busca reforzar el pericampo, dar cierta visibilidad a la segunda dimensión.

Si el cronotopo alude a las dimensiones chronos (tiempo) y tópos (espacio), pero el quinto stadium del soporte implica la transformación de este último al nivel de su estructura física, lo que este estudio plantea es la sustitución del tópos por el morphos (forma). Por ello, la resultante de la unión cronotopo fantástico y cronotopo gráfico más la alteración de su soporte, será el cronomorfo, la transmutación del soporte físico convencional para generar un evento fantástico espacio-temporal dentro de la narrativa gráfica (Ver Figura 10).

Para explicar esto es necesario sumergirnos en mis propias bitácoras de producción. Es preciso recordar los cronotopos fantásticos mencionados con anterioridad: el expandido, el circular y el bifurcado. Para el primero lo que se busca es generar la sensación de apertura entre una viñeta y otra para crear efecto de estiramiento temporal. La estructura elegida fue la de acordeón, que si bien no resulta muy elaborada ni novedosa en el ámbito editorial -podemos encontrar algunos álbumes ilustrados, art books y otros- permite mantener secciones ocultas hasta que el lector decida desplegarlas, y con ellas, el espacio-tiempo del 

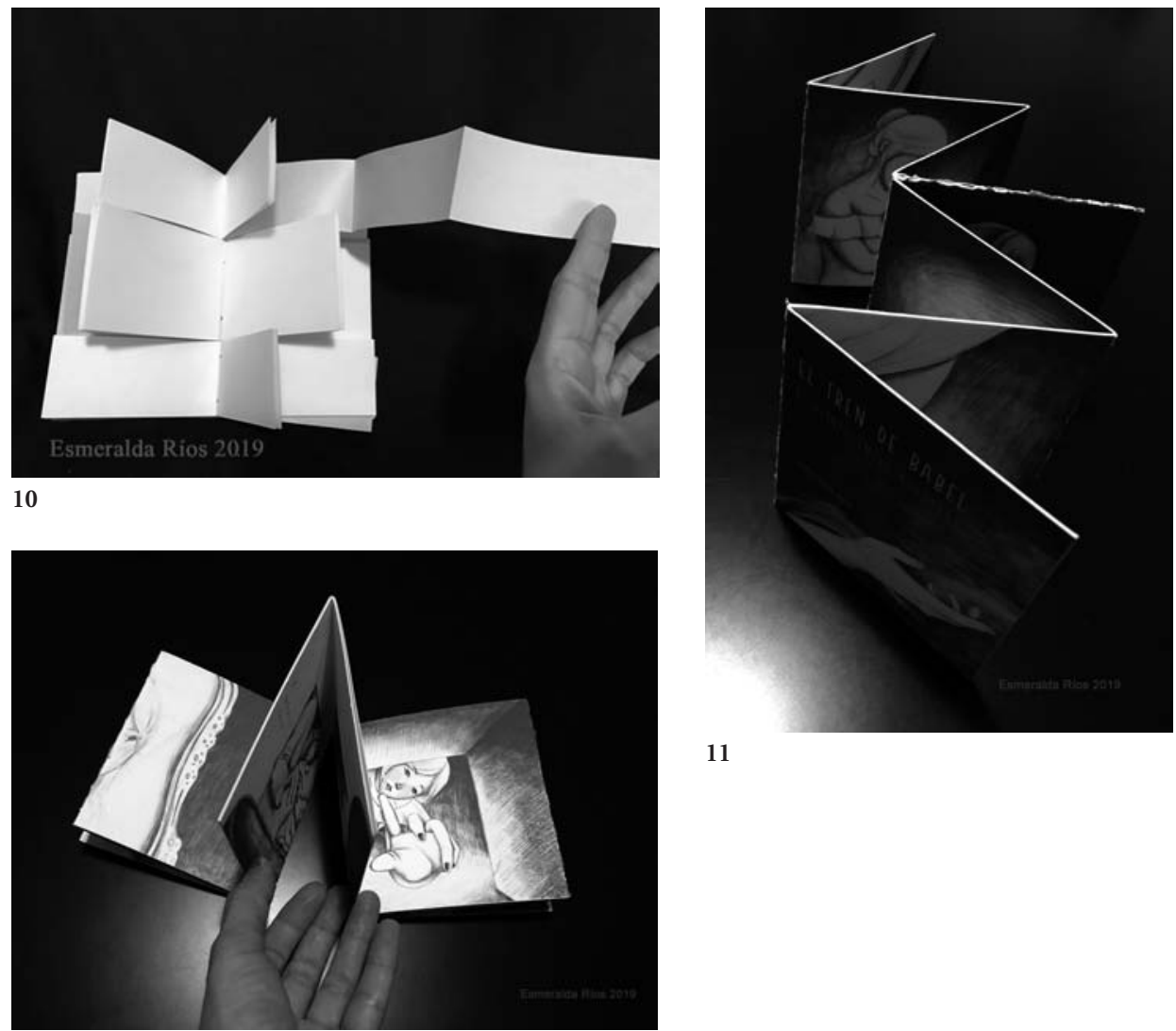

11

12

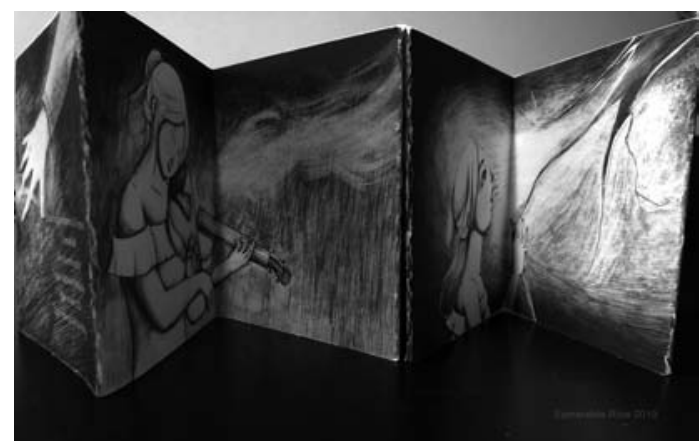

13

Figura 10. Ejemplo de cronomorfo fantástico (2019), quinto stadium propuesto en la presente investigación.

Figuras 11, 12 y 13.

Cronomorfo expandido

(2019) aplicado a

narrativa gráfica personal

El tren de Babel, en

construcción.

relato. Lo interesante es hacerlo con intensión narrativa, usando las crestas del acordeón como puntos anacrónicos. Cada cara puede ser una viñeta completa o un conjunto, en donde tendríamos dos niveles de espacios divisorios, uno dentro del soporte (blanco intericónico) y otro dado por el soporte (dobleces). (Ver Figuras 11, 12 y 13) 
En el cronotopo circular un primer acercamiento es el permitir, mediante un sistema de sujeción de folios, por ejemplo el arillo, la apertura total del objeto libro, donde portada y contraportada se enganchen a la inversa, de tal manera que la lectura pueda comenzar en cualquier página dado que todas convergerán en el mismo principio. Esta, empero, se aleja poco del formato códex.

Una segunda propuesta es la de enmarcar el cómic en un disco, basado en la estructura del zootropo de animación o del círculo cromático, con una ventana -o más- indicadora de la lectura, misma que funge como blanco intericónico. Este presenta la ventaja de tener varios estratos narrativos, lo que también se presta, como las cajas chinas, a contar con una estructura metaficcional. (Ver Figuras 14 y 15).

Como último ejemplo aquí expuesto, el cronotopo bifurcado, que emula el recurso textual de Rayuela -ahora conocido como "libro juego"- en el que el lector puede elegir entre una serie de opciones donde ha de continuar la lectura, pero la variante es que ante el lector "se desplegarán" las distintas líneas temporales, no como un mecanismo comunicador entre folios, como en Meanwhile, sino como ramificaciones del mismo soporte. Para esta, partí de una retícula construida a través de cuadrados como células o unidad mínima estructural (Ver Figuras 16 y 17).

Este mismo cronotopo puede representarse también mediante la estructura de las tablillas mágicas, juguete tradicional que da la ilusión de aparecer y desaparecer paneles. De acuerdo al contenido, también puede utilizarse como cronomorfo anulado-tiempo inexistente-. Lo que nos permite es tener tres viñetas intercambiables dentro de cada tablilla, con lo que presenta posibilidades amplias de líneas cronológicas y la ilusión de fragmentación de las mismas. Estos cronomorfos han sido probados en un proyecto personal titulado El tren de Babel, en el cual llevo algunos años trabajando (Ver Figuras 18, 19 y 20).

Lo que persiguen estas propuestas es apoyar el discurso narrativo del cómic con la forma, incluso ser la base sobre la que se construya la narración, y la que decida el curso que esta ha de tomar, sustituyendo los blancos intericónicos por espacios inhabitados.

Se trata, ante todo, de quitar un poco de control al autor, tan codiciado por los narradores, para introducir un mínimo de factor de entropía, donde creador y lector, no solamente puedan co-crear sino que además tengan que reconocer que no pueden comprenderlo todo. Ni el universo, ni los juegos del espacio-tiempo, ni aún el relato en el que se sumergen.

Figuras 14 y 15. Propuestas para cronomorfo circular (2019 y 2020). Figuras 16 y 17. Estructura para el cronomorfo bifurcado (2020); en la segunda se muestra un ensayo de Borges y Bioy donde reflexiono gráficamente sobre su concepción del tiempo. Figuras 18, 19 y 20. Propuestas para cronomorfo bifurcado o anulado (2019 y 2020). En las fotos 15 y 16 se muestra el cronomorfo aplicado a la narrativa de mi autoría El tren de Babel, en desarrollo. 

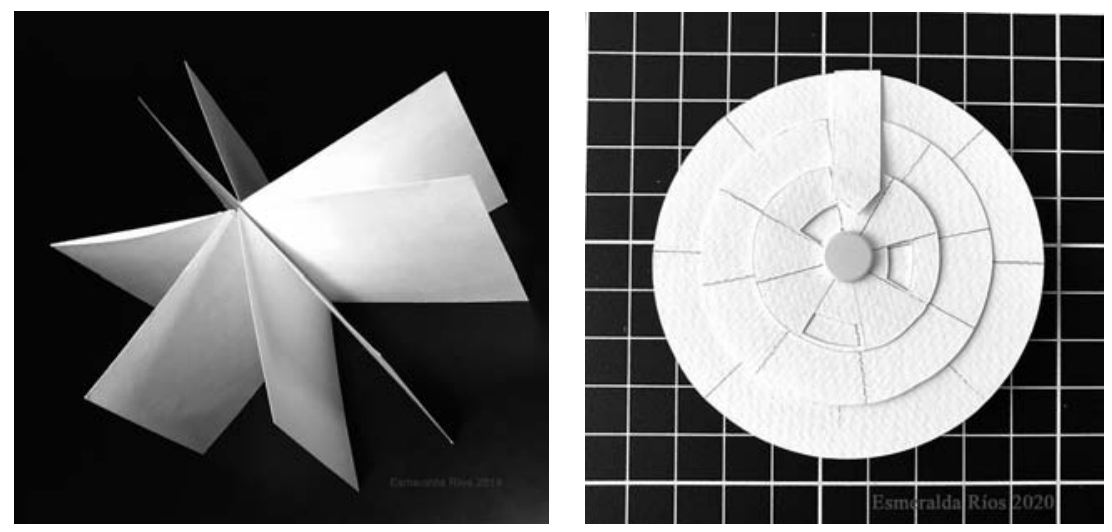

14

15
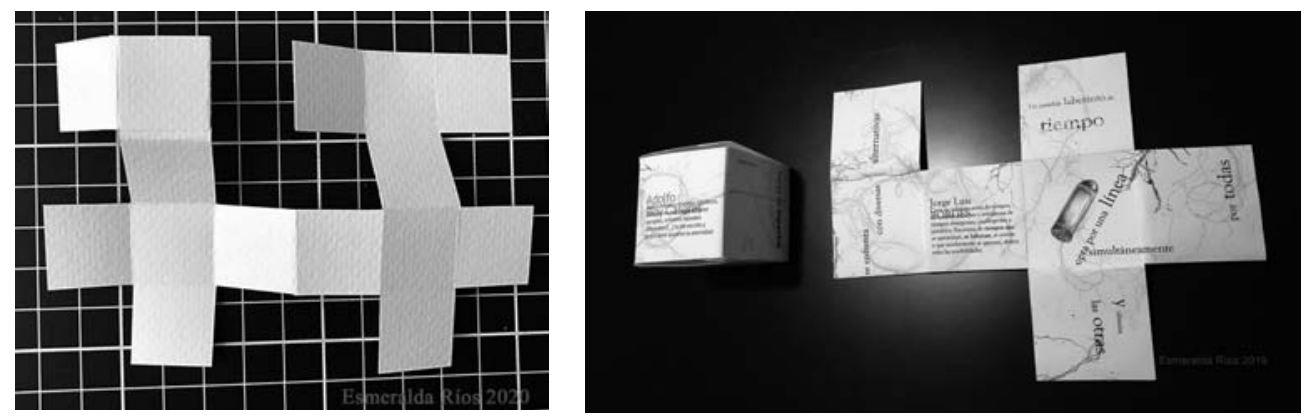

16

17
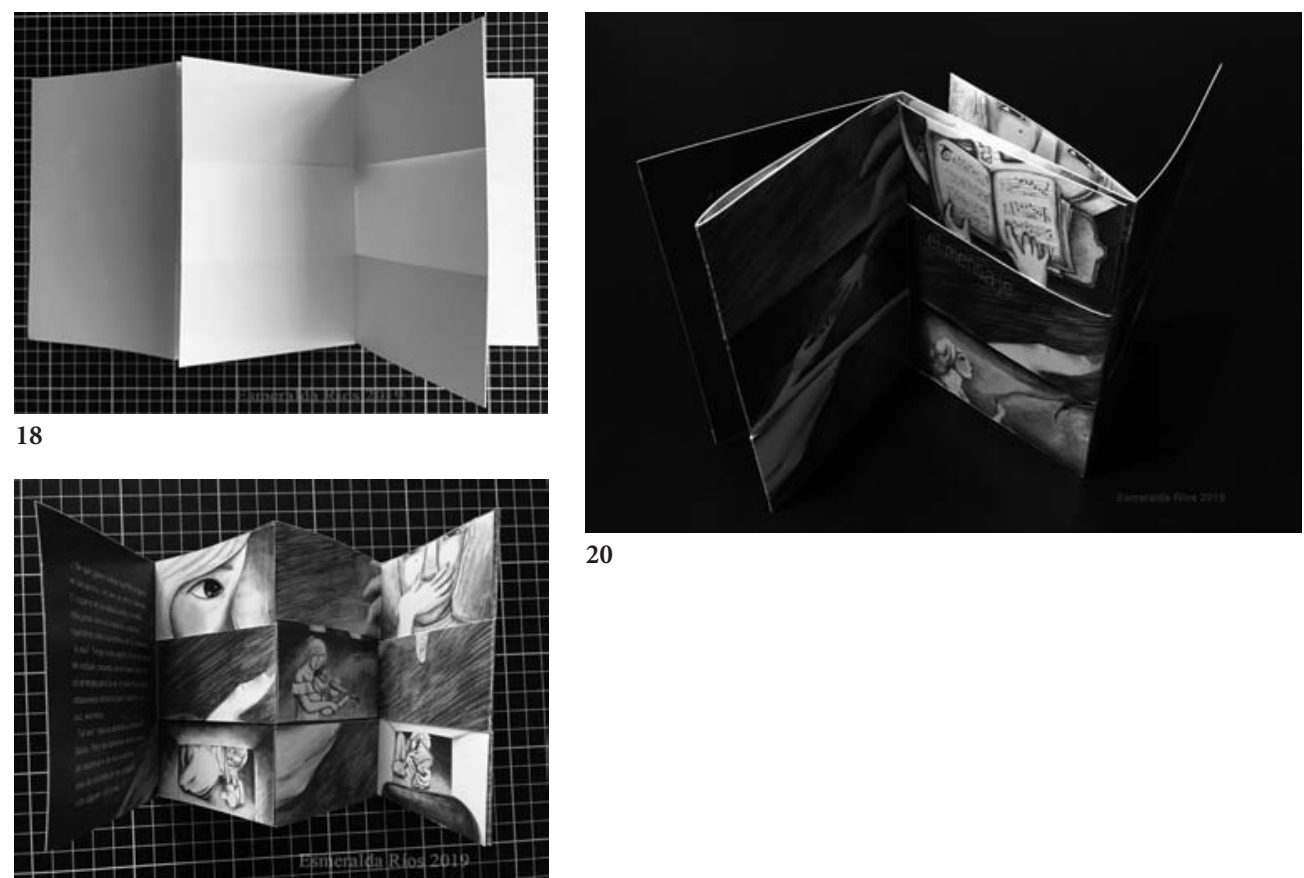

20

19

Cuaderno 123 | Centro de Estudios en Diseño y Comunicación (2020/2021). pp 119-140 ISSN 1668-0227 


\section{Conclusión}

Para cerrar, corroboro lo planteado por los teóricos referidos en la presente: Que el tiempo en la narrativa gráfica transcurre dentro y en el breve espacio entre una viñeta y la otra, entre páginas e incluso entre tomos, empero, sostengo, es posible ir más allá en la utilización de los espacios vacíos conocidos como calles, de las páginas nombradas continentes. Es en estos lugares inhabitados, precisamente, donde el tiempo puede expandirse, contraerse o incluso anularse de manera increíble, lo que devendrá en una estructura física alternativa capaz de enriquecer o incluso construir la narrativa misma. Esto es lo que denomino el cronomorfo fantástico.

La experimentación de suajes, fuelles, desplegables y otros recursos, se vuelve una herramienta poderosa para el narrador gráfico en la búsqueda de reforzar, innovar y profundizar en conceptos abstractos, normalmente intangibles para el lector, como lo es el tiempo en su concepción contemporánea. Sea la presente un aporte a los mecanismos narrativos que derive en una mayor profundidad discursiva.

Por último, como un punto adicional derivado de esta investigación, señalo que esta nueva forma de concebir los soportes gráficos debe incidir también en la generación de esquemas novedosos y planteamientos de producción editorial, abriendo un nicho de oportunidad y, en especial, un tipo de lector distinto, que se involucre más en lo que podríamos llamar el espacio de la creación, ya casi transcurrida la cuarta parte del siglo XXI. Quizá sea esta sus verdaderos riqueza y potencial.

\section{Notas}

1. En La doctrina de los ciclos (2011), Borges refuta la teoría del Eterno Retorno, atribuida a Nietzsche, que postula que las combinaciones del universo son finitas y por tanto debe repetirse de manera idéntica. En El tiempo circular cita a Schopenhauer: "Nadie ha vivido en el pasado, nadie vivirá en el futuro: el presente es la forma de toda vida". En su cuento La trama celeste, Bioy cita a Blanqui (2014), pensador que reflexiona sobre la existencia de múltiples mundos casi idénticos, por tanto, líneas temporales paralelas. Menciono estos solo por poner algunos ejemplos de los conceptos que, de alguna manera, han influido a los autores referidos.

2. Uso como referencia y punto de partida la definición de fantástico enunciada por Tzvetan Todorov en su libro Introducción a la literatura fantástica: "En el verdadero campo de lo fantástico, existe, siempre la posibilidad exterior y formal de una explicación simple de los fenómenos, pero, al mismo tiempo, esta explicación carece por completo de probabilidad interna. Hay un fenómeno extraño que puede ser explicado de dos maneras, por tipos de causas naturales y sobrenaturales. La posibilidad de vacilar entre ambas crea el efecto fantástico" (Todorov, 2016, p. 19), sin embargo, esta definición ha ido cambiando a partir de las lecturas de Roas y Campra. Entre los literatos que analizo la vacilación no está en el personaje, quien acepta a menudo el extrañamiento como algo natural, sino en el lector a quien se le conmina la tarea de creer o no en los hechos presentados. Lo fantástico no 
estriba en el suceso, sino en lo absurdo o extremo de este. Un fantástico que va más allá del acto fantástico. Que causa fascinación, extrañeza u horror -esta última, según Roas (20119, condición para que se presente lo fantástico mas que yo pongo en duda desde la perspectiva latinoamericana donde "todo cabe"- en sus personajes y/o en el lector.

En clasificaciones y terminología en lo referente a la dimensión temporal del relato, así denominada por Pimentel (2017), la teoría narratológica es abundante, por lo que en la presente abordo sólo las más relevante en mi objeto de estudio. Para profundización del tema sugiero consultar a Paul Ricoeur, Luz Aurora Pimentel, Gérard Genette, Svetan Todorov, Lauro Zavala.

3. El concepto de tiempo fantástico no es utilizado por Cortázar, es una propuesta que hago para nombrar, dentro de la presente investigación, al tiempo alterado dentro de la narrativa analizada.

4. McCloud propone el tratamiento de la pantalla, más que como página, como ventana, por lo que no hay razón para moverse como en una convencional, sino más bien desplazarse a lo largo del formato digital, que es infinito. Una ventaja de interés, no interrumpir la percepción espacio-tiempo por la limitante del papel, y por el contrario, explotar la distancia entre viñetas para generar distintos efectos.

5. El verbo "transitar" aplicado al objeto-libro es utilizado por el Dr. Daniel Manzano y la Dra. Mónica de la Cruz Hinojos, creadores y estudiosos del libro de artista/alternativo. 6. Los artistas e investigadores Alicia Portillo -cuyos aportes han sido fundamentales para la comprensión del soporte de la presente investigación- y Rubén Cerrillo de la Facultad de Artes y Diseño, UNAM, México, proponen el quitar al término fanzine, el prefijo fan, y con ello, revalorizar el zine como medio comunicativo.

7. Libro de artista y libro alternativo no son la misma cosa, aunque ambos tengan el mismo origen. Renán sitúa su diferencia en su reproductibilidad; el primero se trata de una pieza única y por ello sus propuestas pueden parecer más arriesgadas, mientras que el segundo tiende a la búsqueda de la reproducción de la obra, siempre en bajos tirajes, por lo que se vale de técnicas como el transfer manual, la estampa, el offset, etc.

8. Concepto retomado de Lauro Zavala, de su libro Principios de Teoría Narrativa (2017), en el que hace una división de la Narrativa gráfica en Clásica, Moderna y Post moderna.

9. Barrero propone el historietema como la unidad mínima del cómic, que puede ser una línea y cada uno de los elementos que la componen. Plantea otros niveles de historietemas, como los esquemas estilísticos propuestos por los autores de cómic y las distintas escuelas que se derivan de la creación historietística -parahistorietemas-, así como de la ruptura de estos soportes convencionales -dada en el suprahistorietema en lo que denomina el ( $f r$ ) factor de recreación.

10. McCloud propone un esquema de transiciones resultantes de la relación contenidoespacios en blancos entre viñetas: moment-to-moment, action-to-action, subjet-to-subjet, escene-to-escene, aspect-to-aspect, non-sequitur (McCloud, 2006 a, p 15). 


\section{Bibliografía y artículos}

Bajtín, M. (1989). Las formas del tiempo y la novela. Madrid: Taurus.

Barbieri, D. (1993). Los lenguajes del cómic. Paidós.

Barrero, M., (2012). "De la viñeta a la novela gráfica. Un modelo para la comprensión de la historieta.” (Coord.) Peppino Barale, A.M. Narrativa gráfica. Los entresijos de la viñeta. México: Universidad Autónoma Metropolitana.

Bioy Casares, A. (2014). La invención de Morel. Alianza Editorial . (2015). Historias fantásticas. Alianza Editorial.

Borges, J.L. (2000). Ficciones. De Bolsillo.

Borges, J.L. (2011). Historia de la eternidad. De Bolsillo.

Carrión, U. (2012). El arte nuevo de hacer libros. México: CONACULTA/Tumbona Ediciones.

Cid Jurado, A. T. (2006) "De la traducción intersemiótica a la competencia intersemiótica". Versión 18. México: UAM, pp. 115-132.

Cortázar, J. (1959). El perseguidor. Buenos Aires: Panamericana.

Cortázar, J. (2014 a). Cuentos completos/1. México: Punto de lectura. . (2014 b). Cuentos completos/2. México: Punto de lectura. . (2016). Clases de Literatura. Berkeley, 1980. México: De Bolsillo. . (2019). Rayuela. España: Real Academia Española/Alfaguara.

Eisner, W. (1994). El cómic y el arte secuencial. Barcelona: Norma Editorial.

Foster, H. (2001). El retorno a lo real: la vanguardia a finales del siglo. Trad. España: Akal. Fuentes, C. (2012). Aura. México: Era.

Golden, A. (2010). Making Hanmade Books. New York: Lark.

Hawking, S., Mandilow, L. (2006). Brevísima Historia del Tiempo. España: Booket.

Indij, G. (2008). Sobre el tiempo. Buenos aires: La marca editora.

Lefevbre, H. (2013). La producción del espacio. Traducido por Martínez, E. Madrid: Capitán Swing Libros.

McCloud, S. (2006 a). Making Comics. New York: Harper Collins Publishers. . (2006 b). Understanding Comics. New York: Harper Collins Publishers, 2006.

Pimentel, L.A. (2017). El relato en perspectiva. México, Siglo XXI.

Pintor Iranzo, I. (2017). Figuras del cómic: Forma, tiempo y narración secuencial. España: Aldea Global, 2017.

Renán, R. (2009) Los otros libros: Distintas opciones en el trabajo editorial. México: UNAM.

Ricouer, P. (2017). Tiempo y narración II: configuración del tiempo en el relato de ficción. México: Siglo XXI.

Roas, D. (2011). Tras los límites de lo real: Una definición de lo fantástico. España: Páginas de espuma.

Todorov, T. (2016). Introducción a la literatura fantástica. México: Ediciones Coyoacán.

Van Der Linden, S. (2015). Álbum [es]. Venezuela: Ediciones Ekaré.

Zavala, L. (2017). Principios de teoría narrativa. México: Naveluz, UNAM. 


\title{
Novelas gráficas
}

Lee O’Malley, B. (2014). Seconds. New York: Ballantine Books.

McGuire, R. (2014). Here. New York: Pantheon Books.

Pacovská K. (1992). MidNightPlay. London: Neugebauer.

Shiga, J. (2010). Meanwhile. New York: Abrams.

Ware, C. (2000) Jimmy Corrigan: or The Smartest Kid on Earth. New York: Pantheon Books. . (2012). Building Stories. New York: Pantheon Books. . (2019). Rusty Brown. New York: Pantheon Books.

\section{Web site}

Da Silva Alves, W. (2008). "La fantástica retornografía en La invención de Morel de Adolfo Bioy Casares”. 22 abr. 2019. Espéculo. Revista de estudios literarios, Universidad Complutense de Madrid, http://webs.ucm.es/info/especulo/numero38/invmorel.html.

McCloud, S. (2009). "The infinitive canvas". 13 feb. 2018, http://scottmccloud.com/4inventions/canvas/.

\begin{abstract}
This article proposes material support as a narrative structure based on the concept of literary chronotope -relationship between space-time with aesthetic intention in literature- by Mikhail Bakhtin, and the contrast with Latin American literature of the 20th century. Although the time in the graphic narrative is found in the visual representation of the space, analyzed by Linden, Barbieri, McCloud, among others, my premise is the way of time in such narrative really inhabits the blank spaces between frames or panels, and proposes the analysis of the support in the comic and the possibility of experimenting with it to deepen into the narrative discourse -while suggesting a classification based on its alteration-. The proposal is the transmutation of such white spaces into cuts, folds, unfolding and other resources that turned into an alternative format/support to get a different temporal perception in the reader, and likewise, give him the feeling of being co-creator of the story; in turn, such alteration of the conventional narrative support will translate into fantastic time. This conception of graphic supports can also influence new editorial schemes and a different kind of reader.
\end{abstract}

Keywords: Graphic narrative - Comic - Material support - Latin American literature Time.

Resumo: Este artigo propõe o suporte físico como uma estrutura narrativa baseada no conceito de cronotopo literário -relação espaço-tempo com intenção estética na literaturade Mikhail Bakhtin e contraste com a literatura latino-americana do século XX. Embora 
o tempo na narrativa gráfica seja encontrado na representação visual do espaço, analisado por Linden, Barbieri, McCloud, entre outros, minha premissa é que o tempo na narrativa realmente habita os espaços em branco entre as painéis e propõe a análise do apoio na história em quadrinhos e a possibilidade de experimentá-la para mergulhar no discurso narrativo -enquanto sugere uma classificação baseada em sua alteração-. A proposta é a transmutação dos referidos espaços em branco em cortes, foles, desdobramentos e outros recursos que transformar-se em um formato/suporte alternativo para alcançar uma percepção temporal diferente no leitor e, da mesma forma, dar a ele a sensação de ser cocriador da história; por sua vez, a alteração do suporte narrativo convencional se traduzirá em um tempo fantástico. Essa concepção de suportes gráficos também pode influenciar novos esquemas editoriais e um tipo diferente de leitor.

Palavras chave: Narrativa gráfica - Quadrinhos - Suporte físico - Literatura latino-americana - Tempo.

[Las traducciones de los abstracts fueron supervisadas por el autor de cada artículo] 